\title{
DEVELOPING LOCAL WISDOM CONTENT IN WEST KALIMANTAN AS ENGLISH LANGUAGE TEACHING MATERIAL
}

\author{
Yusawinur Barella \\ Universitas Tanjungpura, Indonesia \\ Corresponding Email: yusawinurbarella@untan.ac.id
}

Received: 5th of October 2020, Accepted: $19^{\text {th }}$ of November 2020, Published: $24^{\text {th }}$ of December 2020

\begin{abstract}
English is an international language, and almost all Indonesians are aware that most of the teaching materials that use English contain foreign cultural content and topics from abroad. This will cause students to be less aware of the culture of the nation, because they are more focused on understanding foreign cultures. This problem will be incompatible with the goals of national education, which emphasize the development of national cultural identity and the formation of virtuous character, as well as the competitiveness of human resources for the Indonesian nation. This research is the development of teaching materials that aim to produce a product that will later be useful for students in improving their English language skills. In this study also discusses how a teacher can manage their teaching from rich local materials and resources into attractive teaching and learning management.As a teaching material, the product produced is English-language material, using easy-to-understand vocabulary, and is not accompanied by practice questions at the end of the reading, so that students can read calmly.
\end{abstract}

Keywords: Local Wisdom, reading interest, teaching material

\begin{abstract}
Abstrak
Bahasa Inggris merupakan bahasa internasional, dan hamper semua wagra negara Indonesia menyadari bahwa sebagian besar bahan ajar yang menggunakan bahasa Inggris mengandung muatan budaya asing dan bahasan topik yang berasal dari luar negeri. Hal ini akan menyebabkan mahasiswa kurang menyadari budaya bangsa sendiri, karena lebih fokus pada pemahaman budaya asing yang mereka baca. Permasalahan tersebut tidak sejalan dengan tujuan pendidikan nasional yang menekankan pada pengembangan jati diri budaya bangsa dan pembentukan karakter yang berbudi pekerti luhur, serta daya saing sumber daya manusia bagi bangsa Indonesia.Penelitian ini merupakan pengembangan bahan ajar yang bertujuan untuk menghasilkan produk yang nantinya berguna bagi mahasiswa dalam meningkatkan kemampuan berbahasa Inggris mereka. Dalam penelitian ini juga dibahas bagaimana seorang pendidik seharusnya mengelola proses pengajaran mulai dari bahan ajar dan sumber daya lokal yang kaya akan budaya untuk dapat menjadi belajar mengajar yang menarik. Sebagai bahan ajar, produk yang dihasilkan adalah materi berbahasa Inggris, menggunakan kosakata yang mudah dipahami, dan tidak disertai soal latihan di akhir membaca, sehingga siswa dapat membaca dengan adanya beban haus menjawab soal.
\end{abstract}

Kata kunci : kearifan local, minat membaca, materi pembelajaran

Copyright (C) Yusawinur Barella

\section{INTRODUCTION}

Culture is created because of habits, including reading culture. Someone is said to have a reading culture if that person has a sustainable habit and spends part of his time reading. In Indonesia, the culture of reading is not an interesting thing to discuss. The low interest in reading books, especially English books, is an issue that is still being faced by Indonesian 
society today. At the university level, some students even think that reading is necessary if it has something to do with lectures or exams. This very low reading culture is deeply felt by the writer who is an English teacher. There are various factors that cause low reading interest in students in Indonesia, especially in reading foreign language books. One of them is the lack of local cultural elements that are inserted in every textbook. This causes students to feel they have to read something very new to them, which makes their reading interest decrease due to worries about new and difficult vocabularies that will appear later. The integration of various kinds of local cultural content into teaching materials can be done in many ways. According to (Hartini, Isnanda, et al., 2018; Misbah, Hirani, Annur, Sulaeman, \& Ibrahim, 2020; M Wati, Rizka Putri, Misbah, Hartini, \& Mahtari, 2020), the learning process in the world of education will be more interesting When teachers use local wisdom-based teaching materials, and students will be motivated and more enthusiastic in learning, because the learning material is related to everyday life that they can see around them.

Lack of reading interest in students makes the researcher thinks harder to find an effective way of learning language methods. One of them is the improvement of teaching materials. Teaching materials are the main support in the success of the teaching and learning process. As Widodo and Jasmadi in Lestari, (2013: 1) define learning materials as learning materials, methods and evaluations of a teaching and learning process which are summarized in a tool or learning tool, where as a whole, the device is made in an interesting and systematic way to get goals that match the expectations of teachers. This point of view makes it clear that in designing a teaching material, it should be written with instructional principles so that the material can be used optimally by teachers in supporting the learning process. For this reason, quality teaching materials will greatly assist in the formation of the best character of the Indonesian nation in the future.

Forum Group Discussion is the first step carried out by researchers with the lecturers of General English Courses at Tanjungpura University. The Forum Group Discussion was held 4 times. Based on the extensive reading program that is currently being promoted in the Tanjungpura University environment, and with the existence of five local culture books that have been developed previously, the researchers concluded to make teaching materials with the theme of Traditional Chinese, Dayak and Malay Wedding Culture in Kalimantan West.

This research is a development that aims to produce an enrichment book regarding the largest three-ethnic marriage customs in West Kalimantan, which will then become an extensive reading material in English. Making teaching materials based on local culture is expected to help and attract students' interest in reading. The product in the form of book 
contains information on the local culture of West Kalimantan, namely about the dynamics of the marriage of the three largest tribes in West Kalimantan. With the existence of this learning product in the form of enrichment material, several objectives are expected to be achieved, namely: (1) students are able internationally introduce the culture of marriage about the ethnic groups in West Kalimantan; (2) students are able to understand the local culture of West Kalimantan, especially about marriage in West Kalimantan; (3) Students are expected to be able to provide information about the dynamics of marriage in West Kalimantan by using English; (4) Students are able to understand the vocabulary of culture in English.

Researchers and research assistants along with volunteers have made observations to various book sources, such as libraries, which include school libraries, private data collections, regional libraries, and libraries on several campuses, noting that there is no English-language Teaching Material regarding Traditional Chinese and Dayak Marriage Culture. and Malays in West Kalimantan. Researchers and the team also have made observations by interviewing several trusted sources and experts in their fields, and it can be said that West Kalimantan does not yet have a collection of English reading with the theme of Traditional Chinese, Dayak and Malay Marriage Culture in West Kalimantan. Many studies on Malay culture have been carried out, such as on Dayak studies, but none have touched on the use of Malay culture as an English teaching material.

Ahyat in his research revealed two categories of Malay (especially on the Indonesian side), which have the characteristics of being close to Islamic teachings. He described the dynamics of Borneo Malay culture in the 20th century through a historical approach (Ahyat, 2014). Next, Awang, Maros, and Ibrahim (2012) conducted research related to Malay values in intercultural communication regarding the values of Malay culture used in intercultural communication at a state university in Malaysia. Furthermore, Tirtosudarmo (2002) focuses on West Kalimantan from a political demographic point of view by constructing the Indonesian central government's point of view towards the borders of West Kalimantan (Indonesia) and Sarawak (Malaysia). Meanwhile, there are only a few studies on education that touch the use of Kalimantan's culture and nature for learning English. New English education studies include educational methodology and the development of subject matter which is mostly an extension of methods and materials adapted from international sources.

Previous studies have revolved around correlational, experimental, and classroom action problems. Research on the development of English education was first carried out by three Tanjungpura University lecturers who were funded by the Directorate General of Higher Education of the Ministry of Education and Culture in the Higher Education Leading Research 
(PUPT) regarding designing learning forums with English teachers in border and remote areas called English ONTeLL. One of the results is a description of the strengths and opportunities for developing a joint learning forum. The opportunities arise due to central government policies that provide communication infrastructure and pay attention to the village (Ikhsanudin, Salam, \& Fergina, Second Year Higher Education Leading Research Proposal, 2016).

Students' research that touch the local materials for teaching English is produced by Kasmawita and by Aprisama at the master level (S2) of English Education at Tanjungpura University. Kasmawita developed an English learning material called ALCON-PRO. The product of her research is in the form of authentic local content related to the City of Singkawang for projectbased English learning for high school students (Kasmawita, 2015). Meanwhile, Aprisama developed an English learning technique for elementary school children in Singkawang City with a local game for Malay children, named Lel-Lem Tak (Aprisama, 2015). Other studies of students in West Kalimantan have only touched on problems of learning English which are generally also discussed in other areas in Indonesia or also in other countries. There is nothing specific about the local content of Kalimantan.

\section{METHOD}

Research in the process of this product uses a qualitative approach. The qualitative approach used in this research is more inductive, natural and descriptive. Researcher is a lecturer of English Language Courses at all Faculties at University of Tanjungpura Pontianak, who often deal directly with the students with different backgrounds of English proficiency,. Therefore, she has enough experiences to explore the needs of Extensive Reading teaching materials that can help students and readers to improve their ability to read English sources. The locations of this research are Pontianak City, Kapuas Hulu Regency, Tayan, and Mempawah Regency. Sources of data from this study are ethnic Malay, Dayak and Chinese cultural leaders in West Kalimantan, traditional leaders, people who live in the Malay, Dayak and Chinese cultural environment. Meanwhile, the source of data is collected by means of snowball sampling of informants, where the data collection process will be stopped when the research is considered saturated, or the data collection is maximal.

Data will be collected as expected if the implementation is carried out according to proper procedures. In-depth interview (in-depth interviews) is a data collecting technique chosen by researcher. By using this technique, it is hoped that the data will be obtained fundamentally and specifically, because the guidelines used in this technique are not absolute or loose, or commonly known as unstandardized interviews. The researcher also used the focus group interview technique in this study, where the researcher collected several groups that varied in 
obtaining the data. The use of Focus Group Discussion will be stopped when the researcher has obtained maximum or saturated data or information. Study of Documents is also used by researchers to obtain non-human supporting data, such as documentation of marriages that occurred in Sambas, Malay and Chinese cultures.

Basically, researcher has been analyzing data since the researcher conducted the preliminary study, but data analysis will be more precise if it starts when the data has been obtained. The data obtained by researcher through surveys and interviews, questionnaire answers, personal documents owned by informants, notes, transcripts of interviews with informants, official documents and, subsequently reviewed, studied and evaluated. This research uses data analysis with the Spradley (1980) model, as follows: (1) Domain analysis; (2) Taxonomy Analysis; and (3) Component Analysis. Validation of research results needs to be carried out in an effort to gain credibility of research results, including: (1) Extension of observation time; (2) Triangulation; (3) Member check; (4) Audit trail; \& (5) Expert opinion. The stages carried out in this study are: The stage before data collection in the field, which includes the preparation of a research design (research proposals and instruments); determine the research field; initial information or data collection; and preparation of research equipment, then proceed to the work stage or direct data collection in the field which includes limitations on research background; data collection (observation, interviews, documentation); and checking the validity of the data, and the last stage is the data analysis stage.

The data taken in the preparation of this textbook were obtained by observing and interviewing a number of sources who knew in detail the traditional marriage procedures of each tribe carried out by researchers and research assistants and several volunteers during the last four months. Several interviews were conducted online, due to situations that made it impossible for researchers and the team to go directly to the field. However, the results of the interview can be said to be valid, because they are accompanied by written evidence. There are approximately 16 steps of the development process carried out in this development. In sequence, the steps are: standard setting, data collection, product design preparation, design evaluation, design revision, text compilation, image selection, image integration into text, layouts, book internal evaluation, text evaluation, text correction. , improved book layout, limited external evaluation, and revisions.

After conducting observations and interviews with a number of middle school teachers, lecturers and first-year students, they expressed the same opinion about the importance of introducing the local culture of West Kalimantan using foreign languages into classroom learning, because this type of learning will benefit not only one, that is, in addition to learning 
English, students will indirectly know or deepen their knowledge of the local culture around them.

\section{FINDINGS AND DISCUSSION}

To support the teaching and learning process of English related to local wisdom, Kalimantan has an abundance of resources to share and learn. Most of these sources of culture and local wisdom have been researched by previous researchers, but for learning English, only a few West Kalimantan cultures are raised. This research is a research on the development of teaching materials which aims to continue the findings that have been carried out in previous studies, and the end of this research is to create a product that will be useful in the needs of the teaching and learning process.

The existence of Chinese in West Kalimantan has been around for thousands of years, so that the culture that exists in this Chinese tribe become local wisdom of West Kalimantan which must be widely introduced, guarded and preserved. One culture that is interesting to discuss is the culture of marriage. In the traditional Chinese wedding culture, there are many steps that must be prepared by the prospective spouse and prospective family before marriage, during marriage and after marriage. These many trinkets contain many elements of moral messages, and until now, they are still being carried out from generation to generation. However, there are also many young Chinese women who have begun to eliminate several stages of marriage, citing their busyness and materials that are hard to find in today's world. In addition, several stages were also considered very troublesome because they required a lot of funds. They prefer the easier and shorter way of carrying out the marriage.

\section{Dayak Tamambaloh Marriage Custom}

The Dayak Tamambaloh tribe is one of the Dayak tribes in West Kalimantan. Most of these tribes live in the Kapuas Hulu area. The culture contained in the Dayak Tamambaloh tribe is still well preserved today, including the culture of marriage. Although many young people have studied or worked outside Kapuas Hulu, they still practice their customs to preserve culture. The majority of Dayak Tamambaloh tribes are Catholic. Before carrying out a religious marriage in the church, the Dayak Tamambaloh community first carried out a traditional marriage to complete their marriage. Similar to Chinese culture, the Dayak Tamambaloh community also has stages that are not easy to do before the wedding, the wedding day and after the wedding. However, this culture is still being carried out today, so that it is not lost to the times. 


\section{Melayu Sambas Marriage Custom}

The Malay tribe is one of the three largest tribes in West Kalimantan. Living side by side peacefully with other tribes in West Kalimantan, this tribe can mingle and become scattered in all corners of West Kalimantan. The Sambas wedding culture is not much different from the Malay wedding culture in West Kalimantan, so it can be said that the Malay tribes in Kalimantan do almost the same things that the Sambas Malay people do in the wedding procession. However, there are still some differences that characterize the Sambas community, which are not carried out in other Malay communities.

\section{CONCLUSION}

Teaching English has been applied for a long time in Indonesia. Along with technological advances and globalization, nowadays students' English proficiency is more concerned. But in reality, Indonesia still ranks quite low among other countries. Lack of interest in reading in students is one of the causes for this to happen. To improve reading skills and interest in students, interesting learning and teaching materials are needed. Reading books about local wisdom can be a solution. Local wisdom which is an identity that belongs to an area and has unlimited cultural values. Local wisdom of a region is a characteristic that makes it different from other regions.

Several studies have proven that students are more active in learning by using teaching materials based on local wisdom. This is because they already know about the material given, which is related to their daily lives. Vocabulary mastery has also increased quite significantly, because students are challenged and motivated to find new vocabulary that they might understand very well in local languages.

The text and vocabulary used in this local wisdom-based teaching material includes descriptive texts about the marriage process of the 3 largest tribes in West Kalimantan. It is hoped that this product can help educators and parents in directing students to the Extensive Reading program, and can introduce West Kalimantan culture in general and Marriage Culture in particular to international relationships. In addition to producing teaching material products, this product is also expected to provide experience and intellectual property rights for researchers in the form of textbooks with ISBNs, national and international scientific publications, invited speakers in seminars, speakers at scientific meetings, and other activities.

\section{ACKNOWLEDGEMENT}

Researcher would like to extend her gratitude to all parties involved in this research, including the UPT Bahasa Tanjungpura University who provided a lot of research funding so that this teaching material product could be published according to the scheduled time, and the 
reviewers who are willing to take the time to provide suggestions and constructive criticism so that this teaching material can be useful later for learning English. Support from teachers and lecturers of English courses who have taken the time to sit together discussing and evaluating this product. There are also many thanks to the informants who are willing to provide extraordinary information and documentation about the Customs and Marriage Culture of the Chinese, Dayak and Malay Sambas tribes. Finally, the researcher would like to thank the team who is always ready to provide energy and thought assistance so that this teaching material product can be completed on time.

\section{REFERENCES}

Ahyat, I. S. (2014). The Dynamics of Malay Culture in West Kalimantan in the 20th Century. Journal of Education and Learning., 8(3), 273-80.

Aprisama, S. (2015). Teaching Technique Development for Elementary School Students in Teaching Listening and Speaking: A Development Research at SD Negeri 17 Singkawang Tengah. Universitas Tanjungpura.

Awang, N., Maros, M., \& Ibrahim, N. (2012, May). Malay Values in Intercultural Communication. International Journal of Social Science and Humanity, 2(3), 201-5.

Hartini, S., Firdausi, S., Misbah, M., \&Sulaeman, N. F. (2018). The development of physics teaching materials based on local wisdom to train Saraba Kawa characters. Jurnal Pendidikan IPA Indonesia, 7(2), 130-137.

Ikhsanudin, Salam, U., \& Fergina, A. (2015). ONTeLL sebagai Sara Pengembangan GuruGuru Perbatasan dan Terpencil (Tahun Pertama). Pontianak: Universitas Tanjungpura.

Ikhsanudin, Salam, U., \& Fergina, A. (2016). ONTeLL sebagai Sarana Pengembangan GuruGuru Perbatasan dan Terpencil: Tahun Kedua. Pontianak: Universita Tanjungpura.

Ikhsanudin, Salam, U., \& Fergina, A. (2016). Proposal Penelitian Unggulan Perguruan Tinggi Tahun Kedua. ONTeLL sebagai Pengembanga $n$ Guru-Guru Perbatasan dan Terpencil. Pontianak: Universitas Tanjungpura.

Iskandarwassid, dan H. Dadang Sunendar. (2011). Strategi dan Model Pembelajaran Bahasa, Bandung :PT Remaja Rosdakarya.

Kasmawita. (2015). Developing ALCON-PRO in English Teaching and Learning for Senior High School 1 Singkawang: The Implementation of Curriculum 2013. Pontianak: Universitas Tanjungpura. 
Lestari, Ika. (2013). Pengembangan Bahan Ajar Berbasis Kompetensi: Sesuai dengan Kurikulum Tingkat Satuan Pendidikan. Padang: Akademia

Rizal, Syamsul. (2019). Desain Pengembangan Bahan Ajar "English For Spesific Purpose" Berbasis Study Islam Dalam Matakuliah Bahasa Inggris Perguruan Tinggi Keagamaan Islam. Nuansa. 12. 10.29300/nuansa.v12i1.2110.

Sibarani, R. (2012). Kearifan lokal: Hakikat, peran, dan metode tradisi lisan. Jakarta: Asosiasi Tradisi Lisan (ATL. 